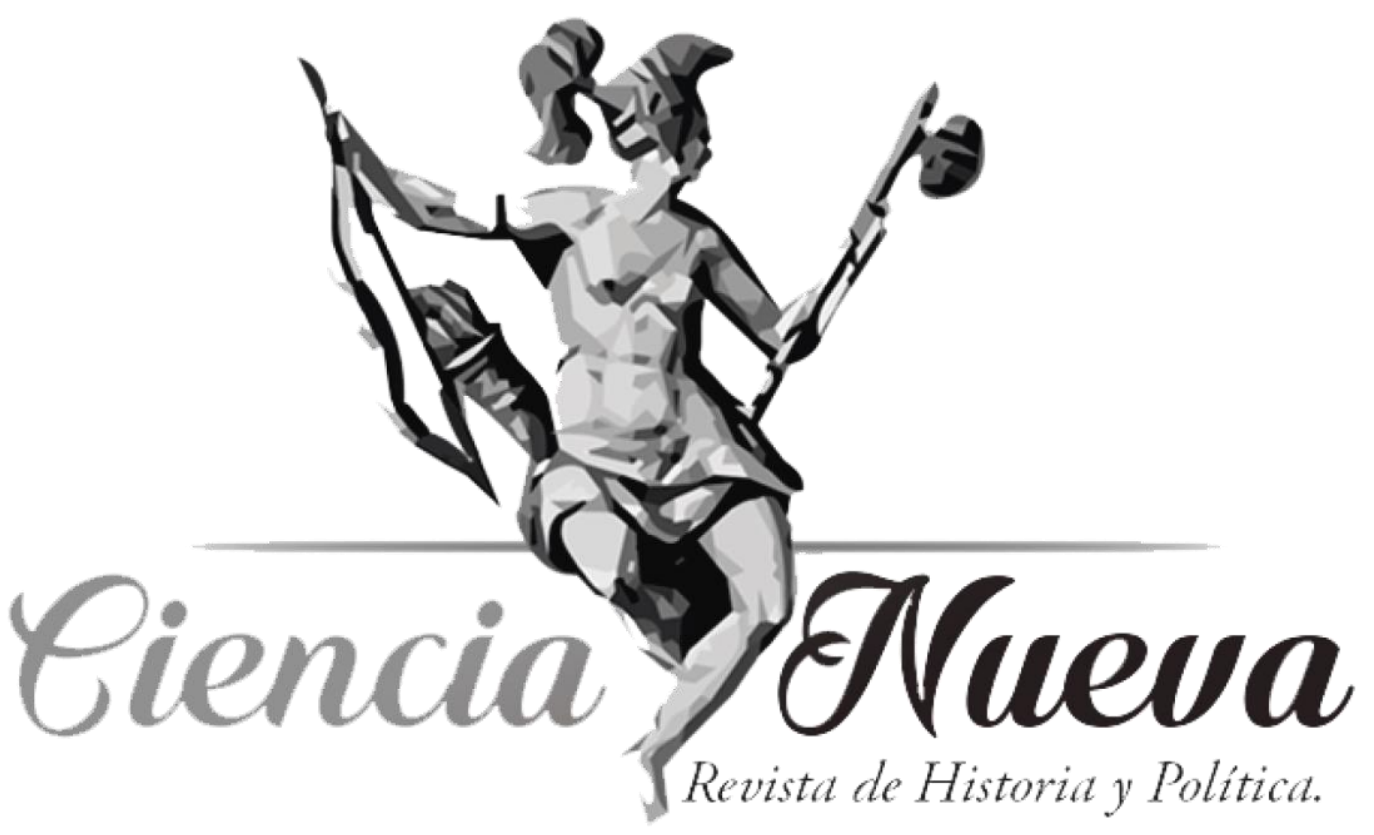

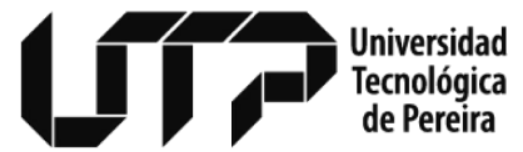

Maestría en Historia

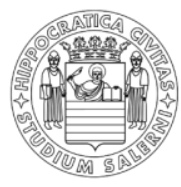

UNIVERSITÀ DEGLI STUDI DI SALERNO

Maestría en Ciencia Política

DOSSIER

GLOBAL PERSPECTIVES OF LATIN-AMERICAN HISTORY

INTRODUCTION: LATIN AMERICA IN THE GLOBAL TIME

INTRODUCCIÓN: LATINOAMÉRICA EN EL TIEMPO GLOBAL DOI: https://doi.org/10.22517/25392662.22571

Daniel Emilio Rojas Castro (MCF), Guest Editor

Vol. 3 Núm. 1 | Enero-Junio de 2019

Pereira, Colombia 


\title{
INTRODUCTION: LATIN AMERICA IN THE GLOBAL TIME*
}

\section{INTRODUCCIÓN: LATINOAMÉRICA EN EL TIEMPO GLOBAL}

\author{
Daniel Emilio Rojas Castro $(M C F)^{* *}$ \\ Guest Editor \\ daniel.rojas@univ-grenoble-alpes.fr \\ ORCID: http://orcid.org/0000-0002-4714-6803
}

\section{A starting point to think about the world}

$\mathrm{T}$

Thinking of Latin America as a starting point to understand the articulation of the world in the same spatial and temporal unit is a project so vast and ambitious, that it is enough to discourage the most obstinate of researchers. Although it seems a more fabulous task than possible, closer to the twelve works of Hercules than to the modest possibilities of professional historians, the need to understand the emergence and expansion of a global time that does not privilege a perspective centered on North Atlantic societies is today more relevant than ever. The world is not the same for everyone ${ }^{1}$.

Building a global perspective of Latin American history has a double purpose: on the one hand, it is an invitation to think about the historical experience of the subcontinent through connections, exchanges and circulations between this space and the rest of the world. On the other, it is a methodological challenge for Global history, a new disciplinary field that, despite its global vocation, has created epistemological peripheries and reproduced geopolitics of knowledge that only partially includes large areas of the world such as Latin America and Africa.

Accepting this double purpose to nourish a historical reflection does not mean falling into an intellectual fashion, which desperately seeks themes and problems to legitimize the importance of the global, nor does it restrict the importance of the local dimension to study social phenomena. Like human reality, social disciplines also change over time, reorient their perspectives and pose new questions that require the construction of other tools. What it is, rather, is to accept that when addressing a global scale as an angle of historical observation, questions and answers arise that other fields of social sciences are not able to offer due to their explanatory interests or their working methods ${ }^{2}$. Historical phenomena are not more or less important when they are studied on a broader temporal and spatial scale, as Paul Ricoeur commented, but they are simply different ${ }^{3}$.

\footnotetext{
* This paper was written according to the Declaration on Publication Ethics of Ciencia Nueva, Revista de Historia y Política. This Declaration can be read on the journal's website: revistas.utp.edu.co/index.php/historia ${ }^{* *} \mathrm{PhD}$. in History of International Relations at the University of Paris 1 Panthéon-Sorbonne. Assistant Professor of History, Latin American Studies and International Cooperation, and member of Institut des Langues et Cultures d'Europe, Amérique, Afrique, Asie et Australie (ILCEA4) and Centre d'Études et de Recherches des Hispanistes (CERHIS), Grenoble Alpes University.

${ }^{1}$ Masashi Haneda ( 羽田正), Toward Creation of a New World History (Tokyo, Japan Publishing Industry Foundation for Culture, 2018).

${ }^{2}$ Sebastian Conrad. What is Global History? (Princeton: Princeton University Press, 2016).

${ }^{3}$ Paul Ricœur. La mémoire, l'historie, l'oublie (Paris: Editions du Seuil, 2003).
} 
The articles that make up the present dossier entitled Global Perspectives of LatinAmerican History question the scientific relevance of conceiving an autonomous history of Latin America with respect to other historical experiences and to other continents. The general proposal of this issue of Ciencia Nueva. Revista de Historia y Politica is not to think of the global as an universal category applicable to any event or process, but to take into account that the global scale is a present horizon in the action of certain historical actors, which allows us to understand certain phenomena that have taken place in Latin American societies as a result of their interaction with other societies on the planet.

\section{Latin American Historiography, Global Turn and Decentering}

Latin American historiography assumes the challenge of thinking about globality in order to understand and explain the formation of societies in the region since the end of the seventies. The economic history works of Marxist inspiration that studied the position of the mining economies of Mexico, Peru, Bolivia and New Granada in a world exchange circuit, in which the means of payment circulated from Potosí to Beijing via Seville and London, constitutes a global turn avant la lettre. In this respect, the debt of the Latin-Americanists with the Sensei Carlos Sempat Assadourian is enormous ${ }^{4}$. At the end of the 1980s, the global turn promoted a series of works of cultural history about the $16^{\text {th }}$ and $17^{\text {th }}$ centuries, which studied the expansion of Christianity and the phenomena of miscegenation within the Iberian empires, and opened a dialogue between the history, anthropology and cultural studies 5 . Since then, not only new historical problems have appeared, but also new questions about the complementarity of historiographical categories issue of the Imperial history, Atlantic history, Transnational history and Connected history ${ }^{6}$.

More recently, other fields such as Macro-history, Big History and the History of the environment have allowed us to broaden our knowledge of Latin American societies by situating their own works in broader periods or by including the working methods of Linguistics, Ethno-botany and Biology to access new sources and build novel interpretations $^{7}$. The analysis of inter-continental networks has not only made it possible to place Latin America as an object of study that interacts with other macro-units in different periods of time, but it has also been a way to understand migratory phenomena that have affected certain Latin American societies ${ }^{8}$.

However, it is likely that one of the most interesting questions that has arisen in recent years relates to the usefulness of employing traditional categories of Latin-Americanists as

\footnotetext{
${ }^{4}$ Carlos Sempat Assadourian. «La producción de la mercancía dinero en la formación del mercado interno colonial », Revista Economía, Vol. I, No. 02, (1978), 2-56.

${ }^{5}$ Serge Gruzinski. La colonisation de l'imaginaire, Sociétés indigènes et occidentalisation dans le Mexique espagnol, XVIe-XVIIIe siècle (Paris: Gallimard, 1988).

${ }^{6}$ Bernd Hausberger \& Erika Pani, «Introducción. Dossier Historia Global », Historia Mexicana, No. 177, IxViii, (2018), 183.

${ }^{7}$ Charles C. Mann. 1491: New Revelations of the Americas Before Columbus (New York, Vintage Books, 2005); Mark Carey. «Latin American Environmental History: Current Trends, Interdisciplinary Insights, and Future Directions », Environmental History, Vol. 14, No. 2 (APRIL 2009), pp. 221-252.

${ }^{8}$ Louise Fawcett de Posada. Libaneses, Palestinos y Sirios en Colombia (Barranquilla, CERES-Universidad del norte, 1991); Masahiro Tsujimoto « Migration, economic adaptation and mutual cooperation: Japanese rotating savings and credit associations in Argentina », in Global Migration and Ethnic Communities: Studies of Asia and South America (Balwyn North/Portland: Trans Pacific Press, 2012).
} 
'miscegenation' to study the European societies and the United States 9 . The starting point for such a question is the realization that planetary globalization, migrations and virtual interconnectivity have created forms of cultural hybridization that surpass the Latin American contours. If, for a long time, miscegenation was silenced as the superiority of Western culture was brought to the forefront, or was only accepted as a way of accentuating luxury and wealth within a catalog of exoticisms ${ }^{10}$, the progressive change of cultural and ethnic composition that was operated in Spain, France or Germany since the eighties radically modified institutions such as the family, the school and the company. The cultural references of many adolescents in the metropolitan areas of Paris and Marseille have little to do with the canon of an enlightened culture and are inserted in a global dimension that is almost unrelated to the official narrative of a national history or culture. In that sense, Latin American history can not only contribute to a decentralization of the different genres of European history or an oxygenation of the social sciences, but also to make intelligible social phenomena of a Europe in full mutation through a Latin-american ars interpretandi.

\section{Placing Latin America in Global time}

The contributions of this dossier, opens different perspectives to think about Latin America in global time: phenomena of transfer, appropriation and joint creation of techniques; adaptation of actors on a global scale to obtain promotions and other benefits; creation and working of philanthropy networks linked to political and scientific projects or constructive criticism of a traditional periodization of contemporary history based on the European experience. Each of the articles uses the global scale as a methodological budget or inquiries about how the global is inscribed in the motivations of action of a given actor.

The global turn has contributed to creating new poles in war studies. The commemorations of the First World War prompted a series of works that study the impact of this conflict in Africa, Asia and Latin America, including in this way areas that had not been considered $^{11}$. On the other hand, several works have been dedicated to analyzing the circulation and the joint creation of combat techniques without being limited to observing a unidirectional transfer of these from Europe to other parts of the world ${ }^{12}$. The work of Pedro Miguel Omar Svriz Wucherer pertains to this last field; he opens this dossier with an article entitled From Europe to the Chaco-Paraguayan Frontier. The Jesuit Brothers: Biographical Trajectories, War and Global Histories in the $17^{\text {th }}$ Century.

\footnotetext{
${ }^{9}$ Serge Guzinski. L'histoire, pourquoi faire? (Paris: Fayard, 2015).

${ }^{10}$ Serge Gruzinski. Les quatre parties du monde. Histoire d'une mondialisation (Villeneuve-d'Ascq: SeuilEditions de la Martinière, 2006).

${ }^{11}$ Olivier Compagnon. L'Adieu à l'Europe. Amérique Latine et la Première Guerre Mondiale (Paris: Fayard, 2013); Heike Libau, Katrin Bromber, Katharina Lange, Dyala Hamza \& Ravi Abuja (Dir.) The World in World Wars: Experiences, Perceptions and Perspetives from Africa and Asia (Leiden \& Boston: Brill/Studies in Global History 5, 2010); Jane M. Rausch. «Colombia's Neutrality during 1914-1918: An Overlooked Dimension of World War», IIberoamericana No. 53 (2014), pp. 103-115; Stephan Rinke. Im Sog der Katastrophe. Lateinamerika und der Erste Weltkrieg (Frankfurt am Main: Campus, 2015). Recientemente, un número de la revista Contemporánea abordó la relación entre Guerra y Sociedad, contrastando y conectando las experiencias latinoamericanas con otras partes del mundo. 'Dossier Guerras y política en América Latina en el siglo XX', Contemporánea: Historia y problemas del siglo XX, año 8, Volumen 8 (2017).

${ }^{12}$ Kazuhisa Takeda, «Las milicias guaranís en las misiones jesuíticas del Río de la Plata: un ejemplo de la transferencia organizativa y tácticas militares de España a su territorio de ultramar en la primera Época moderna», Revista de Historia Social y de las Mentalidades 20, nº 2 (2016), 33-72.
} 
Svriz Wucherer analyzes how the Society of Jesus promoted "the circulation of knowledge, training and military weaponry among the Guaraní natives" in the context of the clashes between Iberian empires in America. This confrontation was rooted in the razzias of the Luso-American bandeirantes who entered the territory of the Spanish Jesuit missions in search of gold, precious stones, and indigenous people who were captured and treated as slaves. Several of the Jesuit missions in the area decided to oppose the bandeirantes militarily and for that purpose trained the Guarani Indians in the manufacture of firearms.

If the Iberian empires were planetary constructions headed by a sovereign power, at each moment of their historical evolution it is possible to verify that the condition of their unity contained a certain degree of decentralization in the functions of the government ${ }^{13}$. The tension between a centralizing principle that guarantees unity and the institutional arrangements that allow an autonomous functioning of the different administrative entities of the Spanish Empire, is clearly illustrated in A Global Postal Service: Empire, Reform and Conflict in the Spanish Atlantic in the $18^{\text {th }}$ Century, by Rocío Moreno Cabanillas. This second article explores how the Spanish monarchy, in the framework of the enlightened reforms of the $18^{\text {th }}$ century, promoted a postal reform in America to organize and regulate ultra-marine connections. The reorganization of the system created conflicts between local officials who sought to retain control over their areas of influence and the imperial directives, which sought to modernize communications.

One of the most suggestive points of the article by Moreno Cabanillas is to illustrate how change of scale can be a way of acquiring or multiplying benefits. In fact, when appointed in the postal administration of Cartagena de Indias, Spanish Civil Servants could more easily advance their careers in the imperial bureaucracy, and upon returning to the metropolis, they could enjoy a position that they could not have acquired by remaining in Europe. Mobility in a global space is not only part of a current historiographical problem, but demonstrates the awareness that certain actors had of the need to act as mediators and to access intermediate institutions between the local and global levels in order to obtain concrete returns.

The actors are not always passive agents of the global processes, but they can use them to acquire a political legitimacy that they could hardly obtain at other levels. The formation of feminist networks in the Western Hemisphere proves this well. In The Transnational Feminist Movement in the Americas in the 1930s, Maria Elvira Alvarez suggests that for the feminist groups of the American continent, the hemispheric dimension was useful for lobbying between governments and societies that were unwilling to grant women political and civil rights. Moreover, the activity of feminists during the first half of the $20^{\text {th }}$ century was not limited to demanding the attainment of rights such as women's suffrage, but also included demands that had a wider social and international impact, such as the expansion of child education or the requirement that international conflicts be resolved through peaceful means. This point was particularly important in the mobilization of Ecuadorian, Colombian, Chilean and Argentine women at the end of the Chaco War and in the context of increased tensions that led to the Second World War.

Like other recent works, Alvarez emphasizes the importance of Anglo-Saxon philanthropy and Pan-Americanist discourse as a creator and promoter of hemispheric

\footnotetext{
${ }^{13}$ Manuel Herrero Sanchez. « Paz, razón de Estado y diplomacia en la Europa de Westphalia. Los límites del triunfo del sistema de soberanía plena y la persistencia de los modelos policéntricos (1648-1713), Estudis. Revista de Historia Moderna, No. 41 (2015), pp. 43-65.
} 
networks ${ }^{14}$. For example, the International Committee of Pan-American Women, mentioned in the article, was an agency of the Pan-American Union that served to structure contacts between feminists from the north and south of the continent through meetings and congresses financed with the funds of the participants or by philanthropic organizations from the United States. These networks were created while expanding the hegemony of the US on the continent, however they not only served to support the interests of an emerging world power, but they also acted as a stage for debates, divergences and ruptures among feminists, something that proves that the functioning and evolution of a network does not always obey the interests of its creators.

If constructing a 'history of equal parts' is a desirable goal, there is nothing more counterproductive to the comprehension of social reality than to reproduce visions of the past based on romantic militantisms or innocent perspectives that ignore the place of power and hegemonies in the social development. Both Global history and Latin American history would be incomprehensible without thinking about the categories of empire and colonialism, or without stopping to address issues such as slavery, economic hierarchies or the dynamic of the great powers ${ }^{15}$. Every story has, as Raymond Aron remembered, a tragic dark side ${ }^{16}$. Accepting that a vision of history based on the inexorable progress of a Western civilization has lost its validity in the face of the need to recognize the importance of other experiences, cannot amount to denying the role played by Europe in the worldwide unification of the $16^{\text {th }}$ and $17^{\text {th }}$ centuries $^{17}$, or the dominant role of the United States since 1945 in the export of a globalizing process that was understood by many societies as synonymous of 'Americanization'18. Political hegemonies or economic hierarchies take time to establish themselves, but once they do, they last, reproduce and determine the destiny of millions of human beings ${ }^{19}$.

In fact, placing Latin America in a global time implies confronting those simultaneous documents of civilization and barbarism of which Walter Benjamin spoke of in his thesis on history ${ }^{20}$. Although Latin America offers an original decline of the Atlantic revolutions, the new states began their independent existence under the sign of a deep economic and ideological dependence on Europe that was postponed throughout the $19^{\text {th }}$ century. In pursuing the 'European dream' during the first half of the $19^{\text {th }}$ century, the models of citizenship that were built by Latin-American elites favored racial and social exclusion rather than national unification. On the economic level things were not very different. By integrating into the national and world markets the regions known as the Orientes of the Amazon and the Chaco of Peru and Bolivia from 1850, dozens of indigenous communities

\footnotetext{
${ }^{14}$ About hegemonic networks: Juan Pablo Scarfi. The Hidden History of International Law in the Americas. Empire and legal Networks (New York: Oxford University Press, 2017).

15 Jürgen Osterhammel. Die Verwandlung der Welt. Eine Geschichte des 19. Jahrhunderts. (Munich: C.H. Beck, 2010).

${ }^{16}$ Raymond Aron. La philosophie critique de l'histoire. Essai sur une théorie allemande de l'histoire (Paris: Points, 2018).

${ }^{17}$ Hugo Fazio Vengoa. El mundo global. Una historia. (Bogotá: Ediciones Uniandes, 2013).

18 Keneth Waltz, Interview 'Theory and International Politics' by Harry Kreisler, February 10, 2003, « Conversations with History », Institute of International Studies, University of Berkeley (California). Webcast and Post cast in http://globetrotter.berkeley.edu/people3/Waltz/waltz-con0.html

${ }^{19}$ Fernand Braudel. Civilisation matérielle, économie et capitalisme. XVe-XVIIIe siècle. 3. Le temps du monde (Paris: Librairie Armand Colin, 1979).

${ }^{20}$ Walter Benjamin. Illuminationen. Ausgewählte Schriften, 1. «Über den Begriff der Geschichte ». (Berlin: Suhrkamp Verlag, 2010).
} 
were attacked and subjected to a state similar to slavery to guarantee the exploitation of rubber and of other raw materials that satisfied the demand of the North Atlantic ${ }^{21}$. From 1870, in Argentina, the Conquest of the desert, which displaced the internal border of the republic to the south, occupied a large part of the territories of the Mapuches, Pampas, Renqueles and Tehuelches ${ }^{22}$. One of the results was the increase in indigenous mortality and territorial monopolization on the part of large landowners.

There are no magic formulas to write a more balanced history that does not silence the voice of the losers, nor make the apology of the winners. Finding the right medium is part of a challenge to write a more human history, as much as it is to advocate a historical discipline of broader horizons in which the validity of sources and interpretations that do not take Europe or the United States as the unique centers of modernity and global phenomena, are acknowledged $^{23}$.

Environmental history, the History of agriculture and Global history have made it possible to observe, from a new angle, problems related to rural development that had only been dealt with at the national or regional level. By having new files, and above all, by crossing data that allow us to compare and connect the trajectories of the exchanges of objects and biological agents in different places in Africa, Asia and Latin America, it is possible to observe to what extent the processes of rural development of the 1950s and 1960s are linked. As Diana Mendez studies it in the fourth article of this dossier entitled Maize and the Green Revolution: Guatemala in the Global Context of Agricultural Research, 1954-1964, certain agricultural modernization projects promoted by philanthropic groups, university students and state officials, shaped the world agricultural policies and rural development policies during the Green Revolution. In her work, Mendez shows that the history of corn has not only been immersed in global dynamics for a long time, but that the same product has been the creator of scientific and commercial exchange routes on a planetary scale. Central America, and Guatemala in particular, became a crossroads that allowed the globalization of experimental seeds and new practices of agricultural work and pedagogy towards countries like the Philippines, Cambodia, China, Ghana, Nigeria, Ethiopia, Kenya, Uganda, Rhodesia, South Africa, Angola and Mozambique.

The transfer or the joint creation of a technique does not guarantee its permanence or the possibility of exporting it to other geographical horizons. Contact does not mean connection and connections are only maintained if devices are established that allow them to be perpetuated. One of the most suggestive points of Mendez's article is to illustrate the fact that the export of knowledge and its implementation in a different social and cultural environment requires a network of experts capable of transferring and adapting a set of methods and procedures. Reproducing techniques in other places implies forming agents capable of appropriating them and transmitting them in suitable pedagogical environments

\footnotetext{
${ }^{21}$ Pilar García Jordán. Cruz y Arado. Fusiles y discursos. La construcción de los Orientes en el Perú y Bolívia, 1820-1940 (Lima: IFEA-Instituto de Estudios Peruanos, 2001); Catherine Heymann. L'Oriente Péruvien. Entre construction régionale, intégration nationale et internationalisation du marché (1845-1932). (Paris: Presses Universitaires de France-CNED).

22 Del rio, Walter; Lenton, Diana; Musante, Marcelo; and Nagy, Marino « Discussing Indigenous Genocide in Argentina: Past, Present, and Consequences of Argentinean State Policies toward Native Peoples », Genocide Studies and Prevention: An International Journal, Vol. 5: Iss. 2: Article 3, (2010), 139-159.

${ }^{23}$ Sanjay Subramanyan. Vasco de Gama. Légende et tribulations du vice-roi des Indes (Lonrai: Alma Editeur, 2012). The preface that precedes the French translation of the book by Subrahmanyan is illustrative in this sense; James Sanders. The Vanguard of the Atlantic World. Creating Modernity, Nation, and Democracy in Nineteenth-Century Latin-America. (Duke: Duke University Press, 2014).
} 
such as primary, secondary and higher education institutions. The knowledge transit network does not exist without the participants that compose it and is not beyond their own motivations or interests. The journeys of Central American teachers and researchers to Africa studied by Mendez in the second half of the $20^{\text {th }}$ century are a clear testimony that there is no lasting technical connection that is not backed by an effective pedagogical device.

Should we accept as a corollary of global history the existence of a global past? I tend to think so, but I am convinced that the phenomenological configuration of an experience of the global past does not rest (nor can it rest) on the traditional constructions that privilege national or continental spaces. More than a linear and teleological conception of a time that would lead inexorably to the entry into a modernity of European roots or a specific national construction, the global past would follow a rhizomatic structure, in which a common stalk in permanent growth would nourish and evolve through different roots. Of course, the periodization of a global past implies a criticism and a conceptual struggle with the European periodization of time, since this is the basis of traditional periodization in most societies on the planet ${ }^{24}$.

Latin America and the Construction of a Hegemonic Periodization, the article by Carlos Riojas that concludes this dossier, is simultaneously a historiographical analysis and a work proposal. Riojas analyzes the thematic lines of two of the most influential journals of Global history (the Journal of World History and the Journal of Global History) and based on this he highlights the institutional factors and the types of periodization that explain the peripheralization of Latin America in the field. The relevance of a work based on quantitative and qualitative elements to understand the marginalization of Latin America in the context of Global studies is evident, as the author proves that the majority of papers that study this part of the world in both publications, address it from Modern history —what implies that the Latin-American space is studied through the prism of European imperial history- or since the first decades of the $20^{\text {th }}$ century - in which events such as the First World War and the Crisis of the 1920s, obscure the Latin-American experience. How to oppose this peripheralization? Is of course, to propose other periodizations, to write a renewed and inclusive Global history and that is why I invite readers to read the work of Riojas and to take a position on his proposal ${ }^{25}$.

Speaking of renewal in a recent field such as Global history may seem of little relevance, and yet, at present, it is necessary. Latin American history and Global history share the challenge of ceasing to be seen in the mirror of the North Atlantic and of seeking new horizons for reflection and research in the Asia-Pacific and the South Atlantic ${ }^{26}$. From the thematic point of view, exchanges between the Pacific coasts of the Far East and Latin America have much to offer to a history that can illuminate how Japanese economic and

\footnotetext{
${ }^{24}$ Andrea Komlosy. Globalgeschichte. Methoden und Theorien (Wien, Köln, Weimar: Bohlau Verlag, 2011). Whatever the answer given to this question, the integration of the American space into Euro-Asia and Africa in the course of the sixteenth century continues to be a subject of essential reflection, especially because the category of a "unified world spatially and temporally », Which would produce a first global awareness, would be linked to this period. See about it: Sanjay Subramanyan, Aux origines de l'histoire globale. Leçons inaugurales du Collège de France. (Paris: Collège de France-Fayard, 2014); Schmitt, Carl. Der Nomos der Erde im Völkerrecht des Jus Publicum (Berlin; Duncker und Humblot, 1997).

${ }^{25}$ Other proposals for periodization of global history can be found in Komlosy, Globalgeschichte... and Matthew Brown. «The global history of Latin America », Journal of Global History, Vol. 10, Issue 3, (2015), 365-386.

${ }^{26}$ Alexandre Morelli. « Vida (e morte) da Histórica Global », Estudos Históricos. Dossier Perspetivas Globais et Transnacionais. (Rio J.) vol.30 No.60 (2017), 5-10.
} 
technological flows fade into the rest of the Pacific Ocean, or to a cultural history interested in the reciprocal impact of the Chinese Revolution and the Latin American revolutionary movements, or in short, to a history capable of studying the establishment of commercial and military cooperation between South Korea, Vietnam, Colombia and the Central American and Andean countries. African historiography, practically unknown in the rest of the world, is also a highly suggestive field of work, which can not only help broaden the horizon of Latin American history, but also create a true global reading of Contemporary history ${ }^{27}$. The impact of African decolonization processes on Latin American political movements or the influence of African music on Latin American music are themes that can contribute to a better understanding of certain phenomena of cultural transfer and circulation of people and ideas that do not have the North Atlantic as their epicenter, or in which the European intermediary would be an epiphenomenon ${ }^{28}$.

Delimiting the physical and cultural contours of Latin America with reference to other units implies comparing, establishing similarities and parallelisms, doubting the interpretative utility of certain categories and distancing oneself from a methodological nationalism, which different intellectual traditions (including Latin American ones) are not always willing to be given up. The absence of Latin America in the works of Global history not only results from the editorial choices of various university publications, but also from the parochialism that often accompanies Latin-Americanists. Therefore, placing Latin America in a broader temporality, which places the global scale at the service of a historical explanation, requires a real self-critical capacity and an opening to otherness that makes the understanding of the other a step towards the understanding of oneself. Cultural and intellectual openness to otherness is a sine qua num condition for understanding global problems $^{29}$. To appeal to a global scale without accepting this postulate would be like plowing in the sea ...

The different contributions that make up this dossier do not have as a starting point the need to register in a historiographical tradition or in a particular disciplinary area, but to ask how pertinent is it from the historical and scientific point of view to conceive an autonomous history of Latin Americans that does not take into account other experiences and other world historical trajectories. The peripheralization of Latin America in the Global history or the provincialization of Europe and the United States in the conception of the history of the last five centuries not only requires criticizing what has been done up to now, but to make historical works that escape this optic and examine Latin America, Asia and Africa in global time. This dossier constitutes a modest contribution to this objective.

I wish you a satisfying and fruitful reading.

\footnotetext{
${ }^{27}$ A pioneering contribution in this regard is Luis Felipe de Alencastro. « Le versant brésilien de l'Atlantique sud: 1550-1850 », Annales. Histoire, Sciences Sociales 2006/2 (61e année), 339—382.

${ }^{28}$ For example: Nabuco de Araujo, Rodrigo «A voz da Argélia. A propaganda revolucionária da Frente de Libertação Nacional argelina no Brasil. Independência nacional e revolução socialista (1954-1962) », Estudos Históricos, (Rio J.) vol. 30, no 61, (2017), 401-424.

${ }^{29}$ Romain Bertrand. L'histoire à parts égales. Récits d'une rencontre Orient-Occident, XVI-XVIIe siècle (Paris: Seuil, 2011).
} 